\title{
The Process of Denationalization in Albania in the Light of the Country's Accession Process to the EU
}

\author{
Endri Papajorgji \\ PhD (Uni Graz) Mag. Iur (Uni Graz) \\ Karl Franzens Universität Graz, Universiteti Luarasi \\ endripapajorgji@hotmail.com
}

Doi:10.5901/ajis.2014.v3n4p325

\begin{abstract}
The economic system of planned economy, which was established in Albania with the centralized control of the economy through five-year plans for 45 years and state ownership (private property was abolished in Albania since the Constitution of 1976) as well as the binding of the enterprise to the priorities of the PPSH or to the fulfillment of the plan, led to the reduction of economic output, the rationing of consumer goods and, ultimately, after the political change to the transformation into a market economy. This transformation required a broader reform of the entire economic and legal system by creating a functioning market based in the rules of free market and competition and the guarantee of private property. In this sense the privatization and denatonalization-process were two of the main pillars of the new economic system in Albania that built the foundation of free market economy. In this context, the denationalization - process was accompanied by the deficiency of accurate economic statistics, denationalization strategies, foreign investors, a bad policy implementation as well as delays in the framework of immedialy needed reforms (Åslund 2013). The main objective of this article is to analyze the denationalization - process in Albania in the Light of the Country's Accession Process to the EU. A detailed analysis of this process will help to understand the main, strategies, problems and failures of the Albanian legislator that are and will be sanctioned by the decisions of the European Court of Human Rights based in Strasbourg.
\end{abstract}

Keywords: Denationalization, Economy, law, Albania, EU.

\section{Introduction}

The process of denationalization or reprivatization is understood as a way of restitution or compensation to former owners whose property had been confiscated and nationalized after the Second World War in the socialist countries of the Soviet bloc. It aims to correct the injustices of the communist regime to those who have suffered loss or damage of their property.

The aim of the communist expropriations were the abolition of private property and the destruction of the "exploitative classes". However, the restitution and compensation of property was one of the most urgent tasks for the new democratic governments, especially since in Albania during the 20th century a considerable degree of private property was nationalized. Denationalization is therefore very close to the "fair" restoration of private property, economic expediency (Immenga, 1995) and the prevailing of political interests, because politics determines the conditions under which it intends to rely on the implementation of this process (Borić, 1993). In this sense, reprivatization or denationalization is a confrontation with the past in all ex socialist countries; on the other hand, however, it should be noted that a return of property in the same condition as 45 or 50 years earlier is impossible (Kecskés, 1992). The Albanian denationalization law of 1993 opted for the principle of restitution before compensation as a method of restitution of expropriation after 1944 (Koleva, 2007). The Denationalisation legislation was based in both countries in the principles of justice and law. During the implementation of the denationalization process problems arose, in the presentation of proof for the violations of fundamental principles such as rule of law during the nationalization of private property from the communist regimes.

During the communist era, collectivization was carried out either by confiscation of the property of public enemy or war criminals or by donation or exchange. In this point of view and from the perspective of rule of law, it is easier to establish the illegality of the operation in the confiscation because of political conviction; in voluntary donations, however, (and this was the usual procedure during the agrarian reform), the evidence is more difficult because the donation process evidence was accompanied by witnesses and signatures that demonstrated the (supposed) willpower (Gjeçovi, L. Milo, P. Meta, S. Sadikaj, K. Dyrmishi, F. Rama, B. Mato, K, Papagjoni, E. Kuçuku, F. Lalaj, R, Abdyli, S. Limani, G, 
Verli, H, Vokrri, L. Kosumi, J, Pushkolli, D, 2008). ${ }^{1}$

Another objective of this paper will be the analysis of the implemented methods for the denationalization- and restitution process. At the same time, this paper takes into account the finances of the state and deals with the following question: Who is going to whom for what and at what cost compensate?

\section{Denationalization Process in Albania}

The risk that, representatives of the old political system, would delay the implementation of this process, was predictable, but not the delays caused primarily by a high number of lawsuits of property restitution of former owners and their political activity (Schwartz, L, D'Andrea-Tyson, E, 1992). However, this process in Albania did not started immediately after the entry into force of the privatization law of 18.08.1991. This law didn't anticipate the rules to protect the property rights of former owners, which mainly led to the emergence of the problem that owners of the construction land of the former owners became new owners. Even nowadays, in 2014 - the legal situation is not fully clarified. Generally it is a problem that with perspective and vision could have been avoided.

In April 1993, for the first time, entered into force the law "on property restitution and compensation of former owners", the so called law on denationalization. ${ }^{2}$ This was the first step that the state took on the recognition and protection of private property, which was not respected for more than 50 years (Maho, 2009).

The denationalization law was valid according to article 1 of this law for the former owners or their heirs, if the property was nationalized without compensation through the implementation of law, CoM Decisions and court decisions after 29.11.1994. This law didn't regulate: ${ }^{3}$ a. the land and agricultural land, which was regulated by law no. 7501 "On agricultural land", b. property nationalized during communism from collaborators of the Nazi regime, c. Ownership of the King and the property of foreign commercial companies, d. Property of collaborators of the Communist Party.

As forms of reprivatization, the denationalization law anticipated: a. restitution in kind, b. cash compensations, c. compensation with privatization bonds for the purchase of shares of state enterprises (Maho, 2009).

According to Article 5 of the denationalization law, it was arranged a value for the compensation: a. Through full restitution and compensation up to $10,000 \mathrm{~m}^{2}$, b. For property between 10,000 and $100,000 \mathrm{~m}^{2}$ the compensation included $10 \%$ of the value, c. Property for more than $100,000 \mathrm{~m}^{2}$, compensation often included $1 \%$ of the value.

According to Article 14 of Denationalization Law, relations between former owners in the cities and leaseholders were arranged by Law no. 7652 of 23.12.1992 "On Privatization of state housing". ${ }^{4}$ Law no. 7652 of 23.12 .1992 established that the State should give leaseholders an interest-free loan for 30 years, for the purchase of an apartment or house or other accommodation in the same size in the same area or other area close to the previous and the leaseholder is obligated to use this residence and to restitute the previous to the former owner. Clearly this regulation led to legal problems between former owners and leaseholders that were accompanied with emotional elements (Papajorgji, 2013).

Court decision No. 11 of 27.08.1993 was the subject of a complaint of leaseholders group, who could not privatize their apartment based on Law No. 7652 of 23.12.1992 "On Privatization of state housing", because it was a property nationalized during communism, which according to the principle "restitution before compensation" due to the denationalization law rules should be restituted to the former owners. The Constitutional Court rejected the lawsuit of leaseholders. ${ }^{5}$

The leaseholders based their appeal to the court in the constitutional principle of absence of equality before the law. They argumented that they didn't acquire the right of private ownership for their housings as all other citizens, but their property should be restituted to the former owners. This was seen as a violation in their opinion to the constitutional principle of equality before law for all citizens. This argument was based on the rule of law, under which leaseholders of public property became owners of their leased apartment without paying a fee, or for a fee of 200 US $\$$, while in cases of property restitution to former owners, the leaseholders received from the state a loan in the amount of approximately 1,000 US-\$. The different treatment of these two categories of leaseholders - householders of public housing and householders living in former owner's houses - represented a discrimination. The Albanian Constitutional Court opposed

\footnotetext{
${ }^{1}$ Although the state tried to propagandize the authorization and the enthusiasm of farmers for the collectivization of their land, it used all its resources to perform this process, and forced the people to transfer their property voluntarily to the state.

2 Ligj Nr 7698 Për kthimin dhe kompensimin e pronave ish pronarëve, datë 15.4.1993, FI Z 1993, Nr 5, 345.

${ }^{3}$ Article 24 of law no 7698 of 15.4 .1993$.

${ }^{4}$ Ligj 7652 Për privatizimin e banesave shtetërore, datë 23.12.1992, FI Z 1992, Nr 10, 507.

${ }^{5}$ Vendim i Gjykatës Kushtetuese Nr 11 (Decision of Consitutional Court No 11 of 27.7.1993), datë 27.7.1993, Fl Z 1993, Nr 9, 457.
} 
to this argument, that such a regulation violated the constitutional principal of equality before the law with the argumentation that Equality before the law means that there should be equal rights for individuals or people in same situations. The principle of equality means that same should be treated in the same way, so that individuals, who are in similar circumstances should be treated in the same way. ${ }^{6}$ For this reason leaseholders were not discriminated, but rather advantaged, as they benefited free interest loans to buy or build an apartment or house.

Because of the difficulties and problems that were analyzed in this decision by the Constitutional Court, according to the author, Law no 7689 of 15.04 .1993 "on property restitution and compensation of former owners" was abolished by Law no. 9235 of 29.07 .2004 "on restitution and compensation of property".?.

The new law brought many changes, especially in the context of compensation according to Article 11. According to this regulation, any compensation must be implemented through: $a$. The land within touristic areas, $b$. Land in ownership or use of the state or the Ministry of Defence, but outside the structures of the armed forces, or c. through state corporate shares or companies with joint capital. In addition, this law predicted in Articles 15-20 the establishment of the agency for restitution and compensation of property (AKKP), as the responsible institution for the implementation of the reprivatization process. Leaseholders of reprivatized housings, according to Article 9 were left a 3-year term to restitute the apartments to the former owners.

Based on this new regulation, the leaseholders association charged a discrimination lawsuit with the purpose of abolishment of this rule. The Albanian Constitutional Court decision No. 26 of 02.11.2005, accepted this lawsuit argumenting that Article 9 interferes with Articles 15,17, 18 of the Albanian Constitution on fundamental rights and was revoked as unconstitutional. ${ }^{8}$

The legislator did not take into account the decision of the Albanian Constitutional Court. Law No 9583 of 17.07.2006 "on some changes and amendments" to law no. 9235 of 29.07.2004 "On the restitution and compensation of property", ${ }^{9}$ didn't amend Article 9. This led to another constitutional court decision No. 11 dated 04.04.2007, which declared the amendments of the 2006 law as unconstitutional, bringing the same arguments. ${ }^{10}$

The legislator did not take into account any initiative to solve the problems connected to Article 9 . This created the following situation: for the leaseholders, the legal situation was doubtful, while the owners were not able to take possession of their property. This situation is only a result of the legislator, that didn't find a solution even after 24 years since the fall of communism, for a fair and legal development of reprivatization through property restitution or compensation of nationalized property (Maho, 2009).

On 1.08.2012 the legislator finally approved "Law No. 82/2012 on the approval of CoM Decision of the same date on the transfer of housing to the formers". ${ }^{11}$ This law provides a final restitution for former owners, precisely on 1.11.2012.

In addition, all former owners who didn't receive their right of ownership, should address to the National Housing Entity within 1.11.2012. After the verification of their names, owners will be registered on a list and receive a document from this institution. According to Article 1 of the Law of 01.08.2012, leaseholders were given an interest-free state loan with a 30-year term for the purchase of an apartment or house. Article 4 of this law also stipulates that municipalities must provide to this leaseholders category, maximally half of the housing they build.

This solution was taken especially, after the elections of June 2013 in Albania. A similar solution like this one was considered unconstitutional by the Albanian Constitutional Court in the years before, ${ }^{12}$ but this Court's decision was taken when the government that won the elections in 2005 did not have the majority of the constitutional court members. It is assumed that this law will scatter a new wave of court procedures in Albania.

\footnotetext{
${ }^{6}$ Law No 7491 For the main constitutional provisions, FI Z 1991, Nr 4, 145.

${ }^{7}$ Ligj Nr 9235 Për kthimin dhe kompensimin e ish-pronarëve, datë 29.7.2004, FI Z 2004, Nr 61, 3934.

${ }^{8}$ Vendim i Gjykatës Kushtetuese Nr 26, datë 2.11.2005 (Decision of Consitutional Court No 26 of 2.11.2005) FI Z 2005, Nr 91, 2927.

9Ligj Nr 9583 Për disa ndryshime dhe shtesa në ligjin Nr 9325 datë 29.7.2004 Mbi kthimin dhe kompensimin e Pronës, datë 17.7.2006, FI Z 2006, Nr 81, 2786.

${ }^{10}$ Vendim i Gjykatës Kushtetuese Nr 11, datë 4.4.2007 (Decision of Consitutional Court No 11 of 4.4.2007) FI Z 2007, Nr 46, 1177.

${ }^{11}$ Ligj Nr 82/2012 Për miratimin e aktit normativ, me fuqinë e ligjit Nr 3 të këshillit të ministrave Për lirimin e banesave pronarëve të ligjshëm nga qytetarët e pastrehë, banues në banesat e ish-pronë e subjekteve të shpronësuara, datë 1.8.2012, FI Z 2012, Nr 128, 7180.
}

${ }^{12}$ Vendim i Gjykatës Kushtetuese Nr 26, datë 2.11.2005 (Decision of Consitutional Court No 26 of 2.11.2005) FI Z 2005, Nr 91, 2927. 


\section{Agricultural Land Compensation}

The legal framework of the denationalization process was fully completed with law no. 7699 of 21.04.1993, which regulated the compensation of agricultural land. Article 1 of this law recognized the right of property to former owners of agricultural land who had been the owner at the time of entry into force of "Law No. 108 of 29.8.1945 on agrarian reform". Law No 8024 of 2.11.199513 defined the criteria for the compensation of the former owners of agricultural land. This law implied the compensation of agricultural land in tourist areas and in households (Haxhi, 2007). According to Article 5 of the law of 1995 the former owners had the opportunity, to replace their agricultural land with a land up to 50 hectares, which was not affected by "Law No. 7501 on agricultural land". ${ }^{14}$

In comparison to the denationalization process in urban areas, this law found another solution, which included a cash compensation and replacement of their land with land in touristic areas and in residential areas as well as agricultural land of the same type.

\section{Conclusions}

The denationalization process in Albania showed one thing in full clarity: Albania or the Albanian authorities were totally overwhelmed with the denationalization process. This is largely due to the fact that there were no prescribed legal structures and frameworks, that were able to ensure a proper procedure. Neither existed sufficient legal criterias or a commited administration. To evaluate the process in organizational terms, the adequate word would be "confusion".

In addition, the Albanian state has to compensate large amounts of capital to former owners - this amount is about 4.5 billion US- $\$$, which is $1 / 4$ of the annual budget of Albania. This critical process requires an immediate solution. The frame of cash compensations during the last 4 years (2010-2012) reached the amount of 5 million-\$ U.S., by far the largest amount in 24 years of democracy. ${ }^{15}$ If the compensation proceeds with this amounts, ie U.S. $\$ 5$ million per year, then the denationalization process will not be completed within 2014, as provided by Article 23 of Law No. 9358, but probably this phenomenon will continue for many decades. This paper also showed also a disregard of clear legal and administrative requirements. There was a variety of indeterminate legal concepts, which opened the door for "special" persons, to privatize the property of former owners. On the other hand the constitutional court decisions were not considered by the legislator.

A solution to this problem for all parties (Leaseholders and former owners) would be the creation of a compensation fund, but the government decided to follow another procedure, the transfer of state funds and state property under the jurisdiction of local institutions. Nowadayes, this process is impossible to implement, because there isn't any state property left to restitute to former owners. As a result of the negligence of the Albanian government towards the denationalization process, the Albanian state is sanctioned by the European Court of Human Rights in Strasbourg with large financial amounts; and this is only the tip of the iceberg, because the overall amount that the Government should pay to finish this process will be in the future much higher than the amount of 4.5 billion US-\$.

\section{References}

Borić, T. (1993), Entwicklung der Unternehmensumwandlung und Privatisierung in Kroatien, Slowenien und Ungarn. Privatisierung in Ungarn, Kroatien und Slowenien im Rechtsvergleich.

Gärtner, W. (1996), Die Eigentumsgarantien in den Verfassungen Polens, Ungarns, der Tschechischen und der Slowakischen Republik. Verfassungsrechtliche Grundlagen und Verfassungspraxis, Eigentum in Osteuropa. Peter Lang, Berlin, 219-232.

Gjeçovi, L. Milo, P. Meta, S. Sadikaj, K. Dyrmishi, F. Rama, B. Mato, K, Papagjoni, E. Kuçuku, F. Lalaj, R, Abdyli, S. Limani, G, Verli, H, Vokrri, L. Kosumi, J, Pushkolli, D, (2008), Historia e popullit shqiptar IV.

Haxhi, P. (2007), Regjimi juridik i tokes bujqesore.

Immenga, P. (1995), Privatisierung im Zielkonflikt - Ein Vergleich der Konzeptionen, in Kreuzer, Privatisierung von Unternehmen, p. 54. Kecskés, L. (1992), Editorial Introduction, CEEPN, Reprivatization in Central \& Eastern Europe, p.13.

${ }^{13}$ Ligj Nr 8024 Për Kompensimin e ish-pronarëve të trojeve të zëna, të tokës bujqësore dhe jo bujqësore me troje në zonat turistike dhe në qendrat e banuara, datë 2.11.1995, FI Z 1995, Nr 24, 1074.

${ }^{14}$ Ligj Nr 7501 Për Tokën, datë 19.7.1991, Fl Z 1991, Nr 5, 246.

15 http://lajme.shqiperia.com/lajme/artikull/iden/1046955100/titulli/Buxheti-2011-dyfishohet-fondi-per-demshperblimet (Stand 20.9.2013). 
Koleva, I. (2007), Restitution of expropriated Property, in Fischer/Pleines/Schröder (Hrsg), Movements, Migrants, MarginalisationChallenges of societal and political participation in Eastern Europe and the enlarged EU, p.162.

Maho, B. (2009), Fitimi i pronesise mbi pasurite e paluajtshme.

Papajorgji, E. (2013), Privatisierung von Unternehmen in Albanien und Mazedonien im Rechtsvergleich.

Schwartz, L, D'Andrea-Tyson, E (1992), Reprivatization in Eastern Europe: Roundtable Report, CEEPN, Reprivatization in Central \& Eastern Europe, p. 15.

\section{Legislation and Court Decisions}

Ligj Nr 7698 Për kthimin dhe kompensimin e pronave ish pronarëve (Law no 7698 on restitution and compensation of property of former owners), datë 15.4.1993, FI Z 1993, Nr 5, 345.

Ligj 7652 Për privatizimin e banesave shtetërore (Law no 7652 on the privatization of state housing), datë 23.12.1992, Fl Z 1992, Nr 10, 507.

Vendim i Gjykatës Kushtetuese Nr 11 (Decision of Consitutional Court No 11 of 27.7.1993), datë 27.7.1993, Fl Z 1993, Nr 9, 457

Law No 7491 For the main constitutional provisions, FI Z 1991, Nr 4, 145.

Ligj Nr 9235 Për kthimin dhe kompensimin e ish-pronarëve (Law no 9325 on restitution and compensation of property of former owners), datë 29.7.2004, Fl Z 2004, Nr 61, 3934.

Vendim i Gjykatës Kushtetuese Nr 26, datë 2.11.2005 (Decision of Consitutional Court No 26 of 2.11.2005) Fl Z 2005, Nr 91, 2927.

Vendim i Gjykatës Kushtetuese Nr 11, datë 4.4.2007 (Decision of Consitutional Court No 11 of 4.4.2007) Fl Z 2007, Nr 46, 1177.

Vendim i Gjykatës Kushtetuese Nr 26, datë 2.11.2005 (Decision of Consitutional Court No 26 of 2.11.2005) Fl Z 2005, Nr 91, 2927.

Ligj Nr 8024 Për Kompensimin e ish-pronarëve të trojeve të zëna, të tokës bujqësore dhe jo bujqësore me troje në zonat turistike dhe në qendrat e banuara (Law no 8024 on compensation of property of former owners with agricultural land and touristic land), datë 2.11.1995, Fl Z 1995, Nr 24, 1074.

Ligj Nr 7501 Për Tokën (Law no 7501 on agricultural land), datë 19.7.1991, Fl Z 1991, Nr 5, 246. 
